Michels, Georg B. "Myth or Reality? Ottoman Support for Hungarian Rebels in Light of a Secret Transylvanian Mission to the Porte (1669-1670)." Hungarian Cultural Studies. e-Journal of the American Hungarian Educators Association, Volume 8 (2015): http://ahea.pitt.edu DOI: 10.5195/ahea.2015.220

\title{
Myth or Reality? Ottoman Support for Hungarian Rebels in Light of a Secret Transylvanian Mission to the Porte (1669-1670)
}

\author{
Georg B. Michels
}

\begin{abstract}
The attempt of the Hungarian political elite to form an alliance with the Ottomans after the disastrous Vasvár Treaty (1664) remains one of the least researched topics of Hungarian and Habsburg history. This paper examines the little known attempt of Prince Mihály Apafi, the Ottoman appointed ruler of Transylvania, to intercede on behalf of the Hungarian nobility with Grand Vezir Ahmed Köprülü (1661-1676), the de facto ruler of the Ottoman Empire. The carefully crafted instructions issued to Apafi's secret emissary, the Turkish-speaking Dávid Rozsnyai, and Rozsnyai's detailed report about his encounters with Köprülü and top ranking Ottoman powerbrokers, provide unprecedented insights into the nature of Hungarian contacts with the Porte and reveal the deeply engrained conviction of many Hungarian nobles - both Catholics and Protestants - that becoming the sultan's vassals was the only way to guarantee the survival of an independent Hungarian Kingdom.
\end{abstract}

Keywords: 17th Century Hungary, 17th Century Hungarian-Ottoman Relations, 17th Century Transylvania, Grand Vezir Ahmed Köprülü (1661-1676), Wesselényi Movement

Biography: Georg B. Michels is Professor of History at the University of California, Riverside and is currently writing a book on the Ottoman-Habsburg competition over Royal Hungary during the era of Grand Vezir Ahmed Köprülü (1661-1676). Michels' interest in Hungary and early modern Habsburg-Ottoman relations emerged from his studies on religion, society, and revolt in early modern Russia and the discovery of significant similarities between Russian and Hungarian popular resistance against a centralizing imperial power. Michels has been awarded the American Council of Learned Societies Fellowship (2013-14) and the UC President's Faculty Research Fellowship in the Humanities (2013-14). He has published widely in peer-reviewed journals including Történelmi Szemle, Forschungen zur Osteuropäischen Geschichte, Jahrbücher für Geschichte Osteuropas, Hungarian Studies Review, and Hungarian Cultural Studies: E-Journal of the American Hungarian Educators Association. Trained as a Russian historian and Slavic linguist at the University of Göttingen (Germany), UCLA, and Harvard (Ph.D. 1991) he has written At War with the Church: Religion and Dissent in Seventeenth Century Russia (Stanford, 1999) and co-edited Russia's Dissident Old Believers (1650-1950) (Minneapolis, 2009). 
Michels, Georg B. "Myth or Reality? Ottoman Support for Hungarian Rebels in Light of a Secret Transylvanian Mission to the Porte (1669-1670)." Hungarian Cultural Studies. e-Journal of the American Hungarian Educators Association, Volume 8 (2015): http://ahea.pitt.edu DOI: 10.5195/ahea.2015.220

From the perspective of the Hungarian nobility, the 1664 Vasvár Peace Treaty between the Ottoman and Habsburg Empires was a complete disaster. Not only had the treaty been negotiated without their knowledge after a purportedly decisive victory over the troops of Grand Vezir Ahmed Köprülü at St. Gotthard, it also recognized all major Ottoman conquests, ceded crucial border fortresses, and turned Transylvania - historically the center of Hungarian resistance against the Habsburgs - into an Ottoman puppet state. However, the most painful reality sank in only gradually: marauding Habsburg troops established brutal regimes of billeting rather than to defend Hungarian lands against Ottoman troops that continued to operate in Habsburg Hungary. In fact, by 1666 Ottoman troops had effectively cut Habsburg Hungary in half establishing a corridor all the way from Ottoman territory to the Moravian border (Pauler 1876 1: 45, 62-63, Benczédi 1980: 11-14).

As a result of these dire circumstances, Hungarian nobles initiated secret contacts with the Ottomans. By 1666, Hungarian leaders were in touch with the pashas of Eger and Varad as well as the vezir of Buda (Iankovics et al. 1987 1: 143-147, 616-618, Pauler 1876 1: 63, 91-92). In August 1666 these leaders launched the first diplomatic mission to the Ottoman court to offer the Kingdom of Hungary to the sultan in return for an Ottoman troop withdrawal, recognition of the Hungarian nobility's ancient rights, and protection against the Habsburg reprisals. The historian Gyula Pauler uncovered this diplomatic mission during the 1870s. He considered it the founding event of the so-called Ferenc Wesselényi conspiracy, which he viewed as a plot by the Hungarian aristocracy to secede to the Ottomans. The mission itself was a failure: the Transylvanian emissary finally met Grand Vezir Köprülü a year later — in August 1667—only to have Köprülü reject the offer of submission as untrustworthy and untimely because he was engaged in the siege of the Venetian fortress of Candia on Crete. In addition, Köprülü's Hungarian translator conveyed the details of the meeting to the Viennese court (Michels 2012, Pauler 1876 1: 98-108, 150-55, Benczédi 1980: 19-20).

The so-called Ferenc Wesselényi conspiracy, that is, the secret efforts of the Hungarian political elite to negotiate with the Ottomans after the Vasvár Treaty, remains one of the least researched topics of Hungarian and Habsburg history. The standard work written by Gyula Pauler in 1876 was based on investigations conducted by the Habsburg authorities after the suppression of the conspiracy in June 1670. With the exception of László Benczédi, who adopted Pauler's arguments, modern Hungarian historians have either ignored or downplayed Pauler's findings about the Turkish dimension of the conspiracy. For example, Ágnes R. Várkonyi, one of Hungary's most influential historians of recent decades, criticized Pauler for paying too much attention to archival records that reflected the agenda of the Habsburg court. She suggested that Habsburg investigators had an a priori agenda and distorted historical truth (Várkonyi 2002: 436, 439). Essays by Sándor Bene, Nóra G. Étenyi, and Katalin Toma on the executed Hungarian magnates Ferenc Nádasdy, Péter Zrínyi, and Ferenc Frangepán make similar claims, focusing on the Habsburg propaganda campaign aimed at winning over the European public by mobilizing anti-Ottoman and anti-Hungarian stereotypes (Bene 1997, Étenyi 2002, Toma 2002).

Ottomanists have paid even less attention to Hungarian-Turkish contacts in the aftermath of the Vasvár Treaty. The Hungarian Ottomanist Sándor Papp, for example, lamented the fact that "darkness is still covering the most problematic element [of the Ferenc Wesselényi conspiracy], that is, the "Turkish connection"' [A legproblematiusabb elemet, a "török 
Michels, Georg B. "Myth or Reality? Ottoman Support for Hungarian Rebels in Light of a Secret Transylvanian Mission to the Porte (1669-1670)." Hungarian Cultural Studies. e-Journal of the American Hungarian Educators Association, Volume 8 (2015): http://ahea.pitt.edu DOI: 10.5195/ahea.2015.220

kapcsolatot" még mindig homály fedi]. Papp called for the study of Ottoman manuscripts and documents, undoubtedly a sine qua non for revealing the full nature of Ottoman involvement in Hungarian affairs during the Ferenc Wesselényi conspiracy (Papp 2003: 646). However, the study of the Hungarian-language texts is just as important since many crucial documents remain unstudied even though some of them were published in the late nineteenth century.

This paper focuses on a little known diplomatic mission to the Ottoman Porte that started in October 1669. The mission was initiated by the Ottoman appointed ruler of Transylvania, Prince Mihály Apafi, who claimed to be acting in the name of the entire Hungarian nobility. The emissary chosen for the mission, Dávid Rozsnyai, was a fluent Turkish speaker and an expert calligrapher who was familiar with the Istanbul court. It appears that he was chosen because of his personal ties with leading Ottoman officials. Also, unlike the emissary of the 1666 mission, Rozsnyai did not have to rely on the Porte's Hungarian translator who was a Habsburg spy (Pauler 1876 1: 274, Szilágyi 1867: 5-11). I will first discuss the instructions prepared for Dávid Rozsnyai, and then analyze Rozsnyai's report about his meetings with Grand Vezir Ahmed Köprülü and another high-ranking Ottoman official. Rozsnyai's instructions, which bear the title Memoriale pro generoso domino David Rosnyai [Memorandum for the Noble-Minded Master David Rosnyai], raise many puzzling questions about the nature of Hungarian contacts with the Porte and in particular Hungarian efforts to secede to the Ottoman Empire (Szilágyi 1889: 429431). I will ask some of these questions without necessarily providing answers. Such answers can only be provided by future research in Hungarian, Habsburg, and Ottoman archives.

We probably owe the survival of the Memoriale to a lucky coincidence. Since Rozsnyai's mission was considered top secret and every effort was made to conceal it from Habsburg spies (which is quite understandable after the previous disaster), only two copies were made. Rozsnyai was given one copy of the memorandum that he apparently destroyed after the completion of his mission. The original draft was also discarded - at least there is no trace of it in the archivesbut the second copy was kept by the author and has survived in convoy with letters addressed to Mihály Teleki, a leading Calvinist baron of Transylvania who stood in regular contact with informants in Habsburg Hungary. The nineteenth-century Hungarian historian Sándor Szilágyi discovered this copy of the Memoriale in the archive of the Teleki family. This place of discovery suggests that Mihály Teleki might well have been the actual author, but the Memoriale was written in the name of Prince Mihály Apafi, the Ottoman-appointed ruler of Transylvania (Szilágyi 1889: 431, see also a letter by Prince Apafi to Mihály Teleki dated October 18, 1669, Szilágy 1889: 431). The text of the Memoriale is written in Hungarian with a few Latinisms typical of the chancellery Hungarian of the period.

The Memoriale's introduction explains why it was necessary for Rozsnyai to speak with Grand Vezir Ahmed Köprülü as soon as possible. This mission was considered a matter of extreme imPortence because - so the author claimed - all of Royal Hungary, including Croatia, was ready to secede from the Habsburg to the Ottoman Empire. "We are afraid that this matter will come to the knowledge of His Highness [the grand vezir] by others. May we not be accused of disloyalty towards Our Mighty Emperor [the sultan] and disobedience towards His Highness. We consider the submission of the Hungarian Crown a matter of glory for the Mighty Emperor and therefore... wish to report it now to His Highness" [tartván attól, mások által is az dolog ö nagyságának értésire esik, hogy mi hatalmas czászárunkhoz való hüségtelenséggel, ö 
Michels, Georg B. "Myth or Reality? Ottoman Support for Hungarian Rebels in Light of a Secret Transylvanian Mission to the Porte (1669-1670)." Hungarian Cultural Studies. e-Journal of the American Hungarian Educators Association, Volume 8 (2015): http://ahea.pitt.edu DOI: 10.5195/ahea.2015.220

nagyságához való engedetlenséggel ne vádoltassunk, hat. császár dicsőségére tartozó dolognak tartván az magyar korona béhódolását ...akarjuk most megjelenteni ő nagyságának] (Szilágyi 1889: 429).

The introduction is followed by six points outlining the issues to be covered in the meeting with the grand vezir. Point one emphasizes the usefulness of accepting Royal Hungary into the fold of the Ottoman Empire: "It will be of very great benefit to Our Mighty Emperor and the expansion of his empire" [hatalmas császárunk igen nagy hasznára s birodalmának terjesztésére]. Point two asks for assurances that the sultan will confirm the traditional liberties of Hungarian nobles and "grant them all [possible] assistance against their enemies" [ellenségek ellen minden assistentiával lészen]. Point three explains that, since Habsburg spies had already discovered the plot to secede, the lives of its leaders were in great danger. In order for the plot to succeed, Turkish troops were needed immediately: "May His Highness permit [our undertaking]...by giving us four or five thousand Turkish soldiers who are at home here [in Transylvania] as well as a few troops from the two Wallachian [sic] principalities....If this will be permitted, orders must be given about it to the Vezir of Buda and the two Wallachian voivodes" [Akár csak engedje meg ö nga...négy vagy ötezer itthon lévö török vitézeknek és két Oláhországbeli kevés oláh hadaknak mellénk adásával....Ez ha megengedtetik, erröl mind az budai vezérre s két oláh vajdákra parancsolat kell].

Point four recognizes that the siege of the Venetian fortress of Candia might delay prompt action by the Ottomans. Not yet knowing that Grand Vezir Köprïlü had conquered the fortress several weeks earlier, the Memoriale states: "When the current matter [the siege - G. M.] has been completed the Mighty Emperor should accept this cause and if in the meantime...lives are in danger may we receive [people] with courage and may they be allowed to stay in the land of His Mightiness [on Ottoman territory]" [hogy hat. cs. mostan fenforgó dolgának végben vitele után az dolog acceptáltatik, és az idö alatt ha...életeket veszedelemben forgana, bátorságosan fogadhassuk bé, s lehessen megmaradások az ö hatalmassága országában] (on the Ottoman conquest of Candia and Grand Vezir Köprülü's continued presence in Candia during the following months, see Strauss 1991: 101-6). Point five refers to the terms of the Vasvár Treaty. Strictly speaking, the Memoriale asserts, the sultan "did not make an alliance with the German emperor but with the Hungarian King and the inhabitants of Hungary" [nem az német császárral kötött, hanem az magyar királlyal s Magyarország lakosival] and it was therefore the right of the Hungarians to renegotiate the terms of this peace. A new treaty, negotiated directly between the Ottomans and the Hungarians, would effectively sever the Hungarian Kingdom's ties with the Habsburg Empire. It would also offer great strategic advantages to the Ottoman army by opening up a corridor for military attack against the Venetian Republic via Croatia.

Finally, point six urges Grand Vezir Köprülü to act immediately so that "the Hungarians will not ally themselves with other nations" [az magyarok más nemzetekhez ne kössék magokat]. The Memoriale then assures the grand vezir that the Prince of Transylvania had done everything to restrain the Hungarians from acting prematurely. They were so eager for action that the Hungarian leadership "wanted to approach the Mighty Emperor directly...which [the prince] wished and felt obliged to prevent by bringing the matter to His Highness' attention" [directe hatalmas császárt akarta megtalálni melyet...praeveniálni akarta s tartóztatta, míg Ngdnak értésére adja az dolgot]. Finally, the writer of the Memoriale notes that the grand vezir was the 
Michels, Georg B. "Myth or Reality? Ottoman Support for Hungarian Rebels in Light of a Secret Transylvanian Mission to the Porte (1669-1670)." Hungarian Cultural Studies. e-Journal of the American Hungarian Educators Association, Volume 8 (2015): http://ahea.pitt.edu DOI: 10.5195/ahea.2015.220

only person at the Ottoman court whom he trusted with information about the Hungarian plot; no one else at the Ottoman court — not even the sultan — would be informed. The decision whether or not to intervene in Hungary should be left entirely to the grand vezir's discretion (a wise decision if one considers the towering position of Köprülü at the Porte). ${ }^{1}$

The Memoriale's conclusion urges the emissary to use great caution when sending communications from Istanbul. Also, it emphasizes again the urgency of the mission. Prince Mihály Apafi needed to hear from the grand vezir before making any firm commitments to the Hungarians. Péter Zrínyi, one of Royal Hungary's most powerful magnates, was about to visit the Transylvanian court but "as long as we do not receive a definite answer from His Highness [the grand vezir] we will not give any answer to him [Zrínyi] or anyone else" [sem neki sem másnak, míg ö ngától bizonyos válaszunk nem jö, semmi választ is nem adunk] (Szilágyi, 43031).

Thus, the Memoriale makes three major points. First, the Habsburg Empire's Hungarian borderlands - stretching all the way from Transylvania to Croatia — were on the verge of seceding to the Ottoman Empire. The document also suggests that the Ottoman leadership was not informed about the Hungarian secession. And finally, the document proposes that the Ottomans send troops and get involved in a military conflict that undoubtedly would have broken the Vasvár Peace Treaty with the Habsburgs.

Was the author of the Memoriale well informed? Was Royal Hungary really on the verge of seceding to the Ottoman Empire? If so, why? What had happened to make the Rozsnyai mission so urgent? Was it the discovery of the plot by Habsburg spies? Were the Hungarians really in touch with other nations? If so, which nations? And why would the prince of Transylvania lend his services as an intermediary? Why was he so concerned about preventing direct contacts between Köprülü and the Hungarian secessionists? Also, why did the Memoriale single out the Hungarian magnate Peter Zrínyi who was allegedly on his way to Transylvania? What was his purpose in coming to Transylvania? And finally, why did the writer of the Memoriale trust only Grand Vezir Ahmed Köprülü at the Ottoman court?

Some of these questions were addressed in a top-secret report that Rozsnyai sent from Candia in February 1670 (Lénárd 1882). The report survived in the archive of the Transylvanian magnate Mihály Teleki, the likely author of the Memoriale, and contains intriguing details about six one-on-one conversations between Rozsnyai and Pasha Ibrahim of Aleppo, Grand Vezir Köprülü's chief-of-staff, between January 8 and February 6 and a private talk with the grand vezir himself on January 21, 1670.

In his initial meetings with Pasha Ibrahim, Rozsnyai summarized the main points of the Memoriale and gave the Pasha a more detailed written report in Turkish about the current state of "Hungarian affairs" [magyarországi dolgokrúl]. Pasha Ibrahim read the report and asked some questions. Most imPortently, he wished to know "who among the Hungarian lords were

\footnotetext{
${ }^{1}$ Perplexingly, there are no modern scholarly studies (in any language) on Ahmed Köprülü who, together with his sixteenth-century predecessor Mehmed Sokollu, was the most powerful and longest-reigning of all Ottoman grand vezirs. The most comprehensive introductions remain von Hammer 1830: esp. 225-252, 261-275, 325-330, and Uzunçarş1lı 1951: 410-438.
} 
Michels, Georg B. "Myth or Reality? Ottoman Support for Hungarian Rebels in Light of a Secret Transylvanian Mission to the Porte (1669-1670)." Hungarian Cultural Studies. e-Journal of the American Hungarian Educators Association, Volume 8 (2015): http://ahea.pitt.edu DOI: 10.5195/ahea.2015.220

interested in this affair" [kik vannak a magyar urak közül interessatusok ez dologban]. Rozsnyai answered evasively that many lords were supporting secession from the Habsburg Empire, but Pasha Ibrahim was not satisfied with his answer. He wanted to know whether the Hungarian nobility had made any written commitments, and whether they had sent any letters to the Prince of Transylvania. When Rozsnyai confirmed the existence of such letters Pasha Ibrahim continued: "What if the [grand] vezir...would send a trusted client to the prince to inspect the letters received from these nobles [to see] if the affair is not a fraud" [hát ha most a vezér...meghitt emberit a fejedelemhez küldené az uraktúl jött leveleknek megnézésére, ha nem fraus-e a dolog]? Rozsnyai insisted that the prince would not mind such an inspection but that he would never part with these letters: "He will either burn [the letters] or keep them secret because when such letters come to light...it is wont to cost many people their lives" [vagy elégeti, vagy titokban tartja, mert ez ilyen leveleknek napfényre jövések...sok emberek életeket szokta elfogyatni] (Lénárd 1882: 333-335).

Rozsnyai also discussed the pivotal role of Prince Apafi. The Hungarian lords "no longer want Germans as their kings, but want to elect a king from among themselves and therefore wish to submit themselves to the Mighty Emperor [the sultan]" [már tovább nem akarják, hogy német királyok legyen, hanem magok közül királyt tenni s azért akarnak hatalmas császárhoz hódolni]. Prince Apafi of Transylvania would be the future king of Hungary. Pasha Ibrahim agreed and confirmed that Grand Vezir Köprülü had offered Apafi the Hungarian crown several years earlier. However, he added that the prince had failed to carry out (végbevinni) the grand vezir's wishes. Rozsnyai responded that the prince had not been able to act because he did not have enough support among the Hungarian elite. Now, however, the situation was entirely different: "[The Hungarians] are coming after us. Such a good opportunity must not be squandered. This matter should not suffer any delay" [magok járnak utánunk, az jó alkalmatosságot nem kell megvetni, nem is szenved haladékot e dolog] (Lénárd 1882: 335, 337).

One might add here that Rozsnyai did not speak only in the name of the Hungarian nobility but also on behalf of the Transylvanian court. Contrary to the assertions of the Memoriale, Prince Apafi had dispatched his emissary for another probably even more imPortent reason: he wanted to remind Grand Vezir Köprülü of an earlier promise to make him King of Hungary. Such an interpretation is supported by Mihály Teleki, the probable author of the Memoriale, who reminded one of Apafi's courtiers in a letter dated December 17, 1669-while Rozsnyai was en route to Candia - that Köprülü had offered Apafi the Hungarian Crown in 1663 after Ottoman troops had overrun the Habsburg border defense system and threatened to advance on Vienna. Apafi had then hesitated to accept the crown but now he was ready to become the ruler of Hungary. Teleki expressed his hope that the grand vezir would endorse Apafi's appeal because without Köprülü's endorsement nothing could be done: "If this had been possible [before], I would have put the crown on [His Grace's] head..." [én bizony, ha lehetett volna, koronát tettem volna edig is fejében] (Gergely 1908: 604). Thus, both Teleki and Apafi were invested in a positive outcome of the Rozsnyai mission for their own sake. And they had good reason to be hopeful because during their 1663 meeting the grand vezir had already honored Apafi as the future King of Hungary with the explicit understanding that with Allah's help the Habsburgs would once and for all be ejected from Hungary (Prokosch 1976: 112-114). 
Michels, Georg B. "Myth or Reality? Ottoman Support for Hungarian Rebels in Light of a Secret Transylvanian Mission to the Porte (1669-1670)." Hungarian Cultural Studies. e-Journal of the American Hungarian Educators Association, Volume 8 (2015): http://ahea.pitt.edu DOI: 10.5195/ahea.2015.220

When Rozsnyai finally got to see Köprülü on January 21 he quickly discovered that Köprülü was not at all ignorant about developments in Hungary. In fact, he was apparently better informed than Rozsnyai himself. He pressed Rozsnyai for names and when Rozsnyai responded that he had been instructed not to reveal any names Köprülü rebuked Rozsnyai for being dishonest ("Of course you know" [hogy ne tudnád]) and responded cryptically that it didn't matter because he was himself familiar with the names of the Hungarian magnates involved in the conspiracy. Köprülü then mentioned the names of the magnates Ferenc Nádasdy, Royal Hungary's Palatine and highest ranking dignitary; the magnate Péter Zrínyi, commander-in-chief of Croatia; and Kristóf Batthyány, who was the most powerful magnate of Hungarian regions adjacent to Austria and Moravia. Köprülü paused "to think a little" [egy kevéssé gondolkodván] and finally asked the following question: "Then, for what purpose would the prince [of Transylvania] want the troops" [hát a hadat minek kérné a fejedelem]? Rozsnyai responded that the troops would not be used to start a war with the Habsburg Empire but to help the Hungarians "better concentrate their efforts on the execution of the affair" [hogy inkább összegyülhessenek a dolognak végben vitelére]. Shortly after this remark the conversation was over and Köprülü sent Rozsnyai away with the remark: "Relax. Let's see" [légy vesztegségben, meglássuk] (Lénárd 1882: 336).

It was not a very promising encounter. The conversation with Köprülü was pointedly short and ended abruptly after the matter of military assistance had been raised. Five days later, Pasha Ibrahim relayed the following message to Rozsnyai: The grand vezir did not accept the Transylvanian request for support, nor did he want the Hungarians to become subjects of the Ottomans. "The Turk has not yet had a chance to recover from warfare with the German....The Turkish nation has had enough of warfare, and even if this were not the case, we are afraid of God because we have sworn to maintain the peace in His name... The Hungarian nation is very unreliable and they are liars..." [a török a némettel való hadakozás után csak meg sem nyughatott... a török nemzet is már megunta a hadakozást, de ha ez nem volna is, félünk istentül a kire megesküdtünk a békességnek megtartására ... a magyar nemzet igen állhatatlan és hazug nemzet]. Pasha Ibrahim added that Köprülü no longer trusted Prince Apafi because an emissary dispatched by the Hungarian magnate Péter Zrínyi was also in Candia for talks with Köprülü and had also asked for military help. Why had Zrínyi's mission not been coordinated with the Transylvanian mission? Did the emissaries not know of each other? Rozsnyai responded: "I don't remember that when [the Hungarian lords] sent me they were going to trouble Our Lord the Grand Vezir with another mission" [nem is volt emlékezetben, mikor engement küldöttek, hogy még ök is külön kövétséggel búsitsák fövézer urunkat] (Lénárd 1882: 337-338).

It appears that several basic premises of the Memoriale proved to be erroneous. First, Prince Apafi did not represent all Hungarians contrary to the Memoriale's assertion. In fact, the magnate Péter Zrínyi, who supposedly was on his way to Transylvania to meet with Prince Apafi, had instead sent his own emissary to meet with the grand vezir. Second, the unexpected appearance of Zrínyi's emissary weakened the Transylvanian prince's position. While Pasha Ibrahim and Rozsnyai still considered Prince Apafi the future King in a unified Ottoman Hungary, Grand Vezir Köprülü did not refer to Apafi's candidacy with one word. Also, the grand vezir seemed less interested in supporting Apafi than other magnates. When he asked why Ottoman troops should come to Apafi's assistance it sounded as if he was asking "why should I 
Michels, Georg B. "Myth or Reality? Ottoman Support for Hungarian Rebels in Light of a Secret Transylvanian Mission to the Porte (1669-1670)." Hungarian Cultural Studies. e-Journal of the American Hungarian Educators Association, Volume 8 (2015): http://ahea.pitt.edu DOI: 10.5195/ahea.2015.220

give the troops to Apafi and not to the others who are the real leaders of the conspiracy...?"

Rozsnyai understood that his own mission had become hopeless, but he wanted to know more about the intentions of his competitor, the emissary of Péter Zrínyi. Pasha Ibrahim finally told him that Zrínyi had asked that Prince Apafi be deposed by the Ottomans and replaced by Ferenc Rákóczi, the son of the last independent ruler of Transylvania, who had fled the invading Ottoman troops onto Hungarian territory in 1660. Rozsnyai also learned that Zrínyi-unlike Apafi-had offered a large sum of money, namely a yearly tribute of 12,000 Thaler, equivalent to millions of dollars by today's standards. In return, Zrínyi had asked for 30,000 Turkish troops, several fortresses, and a written charter (atname) by the sultan guaranteeing the inviolability of the Hungarian constitution (Lénárd 1882: 341).

The Rozsnyai mission reveals a little known historical reality: there were at least two competing factions among the Hungarian conspirators. One was represented by Prince Mihály Apafi, the Ottoman-appointed ruler of Transylvania; the other faction was led by the magnate Péter Zrínyi. According to the Memoriale these factions stood in close touch with each other and Zrínyi had accepted Apafi's leadership. In reality, however, the two factions were competing with each other for the grand vezir's favors. When Rozsnyai arrived at the Ottoman court he found himself confronted with intrigues that were explicitly aimed at the overthrow of the Transylvanian prince. One wonders how unified the Hungarian cause against the Habsburgs really was if one faction tried to cut down the other in the eyes of the Ottomans. One also wonders why Ottoman troops were requested by the leaders of each faction? Did they really think about the liberation of all of Hungary from the Habsburg yoke or did they seek to establish their own fiefdoms under Ottoman protection?

Did anything other than the personal ambitions of their leaders separate the two factions? It is noteworthy that Peter Zrínyi was a fervent Catholic and close to leading Hungarian church hierarchs including the primate of the Hungarian Catholic church. He also had personal ties with the Vatican including Pope Clement IX. Zrínyi's candidate for the Transylvanian throne, Ferenc Rákóczi, was one of Royal Hungary's most aggressive supporters of the Counter-Reformation. Zrínyi's other associates, Ferenc Nádasdy and Kristóf Batthyány, whose names Grand Vezir Köprülü had singled out in conversation with Rozsnyai, were likewise brutal champions of forced Catholization (Pauler 1876 1: 60-68, 169-170, 276-277, 281).

Prince Apafi, on the other hand, was a zealous Calvinist who had observed the Habsburg court's promotion of the Catholic faith in Royal Hungary with great alarm. In April 1669, members of Apafi's court had met with Hungarian Lutheran and Calvinist nobles who begged them to approach the Ottoman court for help against the destruction of their faith (Szilágyi 1889: 58-60, 416-418). These Protestant lords put all their hopes in the Ottomans. For example, the Calvinist Ferenc Bónis, who was later executed for treason by the Habsburg court, stated "Hungary and the Hungarian national estates are definitely devoted followers of the Turkish Emperor and... and if the Hungarians remain loyal to him...he will support them in every law and also leave Hungary in its liberties as long as they are part of the Ottoman nation" [Bizonyossan Magyarország és az Magyar nemzetbeli statusok a Török Császár hívei és...ha hüségeket hozzája meg tartyak az Magyarok...az Ottoman nemzetben addig megh segiti őket minden törvényeben meg hagyvan Magyarországat is szabadságiban]. Bónis was convinced that Turkish troops were ready to help the Hungarian nobility against the Habsburg army in case of 
Michels, Georg B. "Myth or Reality? Ottoman Support for Hungarian Rebels in Light of a Secret Transylvanian Mission to the Porte (1669-1670)." Hungarian Cultural Studies. e-Journal of the American Hungarian Educators Association, Volume 8 (2015): http://ahea.pitt.edu DOI: 10.5195/ahea.2015.220

an uprising: "God help me, if we cannot gain justice the vezir of Buda will arrange it [for us]" [Isten engem úgy segéllyen, ha mi ell nem igazíthatyuk, el igazítya a Budai Vezér]. The Calvinist noble László Gyulafi was convinced that "if [we] wish for it the Turkish Emperor will put 40,000 Turks on [our] side" [ha kivántatni fogh, negyven ezer Törököt is ad melléjük az Török Császár]. And the Lutheran noble András Székely believed that 27,000 Turkish soldiers were already camped in the vicinity of the border to help the Hungarians overthrow Habsburg power. ${ }^{2}$

Is it possible that the Catholic faction was more successful than the Protestant faction in lobbying the Ottomans? Did Zrínyi win the grand vezir's support for military action? After all he had promised a large yearly tribute while Prince Apafi had made only promises of helping expand the empire. However, this is hard to imagine unless we assume that the grand vezir was not aware of the reasons for Zrínyi's close ties with the Vatican. Only two months earlier Zrínyi had asked the pope for money and blessings for an anti-Turkish crusade (Pauler 1876 1: 275). In other words, this eminent Hungarian magnate of Croat descent was playing a double game. On the other hand the failure of the Protestant faction seems surprising if we consider that Lutheran and Calvinist nobles like Bónis, Gyulafi, and Székely were clearly placing all their hopes in the Ottomans. They were desperate about the destruction of their faith and did not have any second thoughts about seceding from the Habsburg empire.

It is interesting to note that the Protestant faction did eventually receive Gand Vezir Köprülü's support. When the Habsburg court proceeded to suppress the pro-Ottoman conspiracy in June 1670 the Catholic faction led by Zrínyi begged Emperor Leopold I for mercy - an astounding spectacle suggesting that Catholic grandees were not as serious about secession as Zrínyi's emissary had claimed. By contrast, the Protestant faction did not succumb to the Habsburg court. A still unknown number of Calvinist and Lutheran nobles - possibly thousands - fled to Transylvanian and Ottoman territory. By late 1670 these exiles launched cross border raids with the help of Ottoman troops and the Ottoman-Habsburg border soon became so tense that the Habsburg court anticipated an eminent Ottoman invasion, a fear that would not go away until $1683 .^{3}$

Under these circumstances one wonders what would have happened if the Rozsnyai mission of October 1669 had succeeded. Could a Protestant led uprising supported by Ottoman troops have created an independent Hungarian Kingdom under the sultan's protection? Such a kingdom would have been centered in Hungary's Protestant counties near Transylvania like the small state created by the Lutheran magnate Imre Thököly in 1682 (Kopčan 1985, Varga 2007:

\footnotetext{
${ }^{2}$ Magyar Országos Levéltár (Hungarian State Archives), Filmtár, X 493, Doboz 1805, Egri Káptalan hiteleshelyi levéltara, Protocollum Extraseriale AG, no. 234, Relatio Attestationis contra Rebelles pro parte Fisci Regii (August-September 1670), fols. 267v, 271, 289r; X 22, doboz 5985, Neoregestrata Acta (E148), Fasc. 517, no. 5, Fassiones et Attestationes collectae...pro parte Egregrii Magistri Nicolai Maylath, Causarum Regalium Directoris et Sacrae Regni istius Hungariae Coronae Fiscalis (March-April 1671), fols. 37-38.
}

\footnotetext{
${ }^{3}$ These exiles remain almost completely unstudied despite calls by Hungarian scholars Farkas Deák and Ferenc Szakály to fill this research lacuna (Deák 1883, Szakály 1989). Zsolt Trócsanyi’s study of Teleki and the Kuruc Movement provides a helpful introduction (Trócsanyi 1972: 91-132).
} 
Michels, Georg B. "Myth or Reality? Ottoman Support for Hungarian Rebels in Light of a Secret Transylvanian Mission to the Porte (1669-1670)." Hungarian Cultural Studies. e-Journal of the American Hungarian Educators Association, Volume 8 (2015): http://ahea.pitt.edu DOI: 10.5195/ahea.2015.220

19-39). Perhaps, if such a kingdom had been created more than ten years earlier during the lifetime of Grand Vezir Ahmed Köprülü it would have been more durable. It is unlikely that a Hungarian Protestant state supported by Köprülü-a much better military strategist than his successor Kara Mustafa - would have drawn the Ottomans into the disastrous campaign against Vienna. Also, the Habsburg-Ottoman border would not have been destabilized by a cross border guerrilla war that increasingly drew in Ottoman troops. Thus, the failure of the Rozsnyai mission signified a tipping point that ultimately contributed to the breakdown of the Vasvár Treaty and the renewed outbreak of war between the Habsburg and Ottoman empires in 1683.

\section{Works Cited}

Benczédi, László. 1980. Rendiség, abszolutizmus és centralizáció a XVII század végi Magyarországon (1664-1685) ['Estate Order, Absolutism, and Centralization in late Seventeenth-Century Hungary']. Budapest: Akadémiai Kiadó.

Bene, Sándor. 1997. "Hóhérok teátruma (A Wesselényi mozgalom perei és a hazai recepció kezdetei) ['The Executioner's Theater (The Wesselényi Movement Trials and the Beginnings of their Reception at Home)']." Siralmas jajt érdemlö játék. Magyar nyelvü tudósitás a Wesselényi mozgalomról ['A Game that Deserves a Scream of Pain: A Hungarian-Language Interpretation of the Wesselenyi Movement']. Ed. Emil Hargittay. Pilisczaba: Pázmány Péter Katolikus Egyetem Bölcsészettudományi Kar: 32-85.

Deák, Farkas, ed. 1883. A bujdosók levéltára. A Gróf Teleki-család Maros-Vásárhelyi levelárából ['The Exiles' Archive: From the Family Archive of Count Teleki in Maros Vásárhelyi']. Budapest: M. T. Akadémia.

Étenyi, Nóra G. 2002. "A nürnbergi nyilvánosság és a Nádasdy Mausoleum” ['The Nuremberg Public and the Nádasdy Mausoleum']. Tanulmányok Szakály Ferenc emlékére ['Studies Dedicated to the Memory of Ferenc Szakály']. Eds. Pál Fodor, Géza Pálffy and István György Tóth. Budapest: MTA TKI Gazdaság- és Társadalomtörténeti kutatócsoportja: 121-37.

Gergely, Sámuel, ed. 1908-1912. Teleki Mihály levelezése (1670-1674). A Római Szent Birodalmi Gróf Széki Teleki család oklevéltára ['The Correspondence of Mihály Teleki (1670-1674)']. Commissioned by the Magyar Történelmi Társulat. Vols. 4-6. Budapest: Athenaeum.

Iankovics, József, Péter Kulcsár and Nényei Gáborné, eds. 1987. Bethlen Miklós levelei (1657 1697) ['The Letters of Miklós Bethlen (1657-1697)']. Vols. 1-2. Budapest: Akadémiai Kiadó. Vol. 6/1-2 of Régi Magyar Prózai Emlékek ['Old Hungarian Prosa Mementos']. Ed. Tolnai, Gábor.

Kopčan, Vojtech. 1985. “A török Porte Thököly-politikája” ['Thököly's Policy towards the Turkish Porte']. A Thököly-felkelés és kora ['The Thököly Uprising and its Time']. Ed., László Benczédi. Budapest: Akadémiai Kiadó: 119-127.

Lénárd, József . 1882. "Rozsnyai Dávid egy ismeretlen követjelentése" [“An Unknown

Diplomatic Report by Dávid Rozsnyai']. Történelmi Tár ['Historical Archive'] 2: 332-41. 
Michels, Georg B. "Myth or Reality? Ottoman Support for Hungarian Rebels in Light of a Secret Transylvanian Mission to the Porte (1669-1670)." Hungarian Cultural Studies. e-Journal of the American Hungarian Educators Association, Volume 8 (2015): http://ahea.pitt.edu DOI: 10.5195/ahea.2015.220

Michels, Georg. 2012. "Ready to Secede to the Ottoman Empire: Habsburg Hungary after the Vasvár Treaty (1664-1674)." AHEA: E-Journal of the American Hungarian Educators Association, Volume 5(2012): http://dx.doi.org/10.5195/ahea.2012.69

Papp, Sándor. 2003. "Szabadság vagy járom? A török segítség kérdése a XVII. század végi magyar rendi mozgalmak idején" ['Freedom or Yoke? The Question of Turkish Help during the Hungarian Estate Movements of the Late Seventeenth Century']. Hadtörténeti Közlemények ['Military Historical Communications'] 116: 633-69.

Pauler, Gyula. 1876. Wesselényi Ferencz nádor és társainak összeesküvése ['The Conspiracy of Palatine Ferencz Wesselényi and his Associates']. Vols. 1-2. Budapest: M. T. Akadémia.

Prokosch, Erich, ed. 1976. Krieg und Sieg in Ungarn. Die Ungarnfeldzüge des Großwesirs Köprülüzâde Fâzil Ahmed Pascha 1663 und 1664 nach den "Kleinodien der Historien" seines Siegelbewahrers Hasan A $\breve{g} a$ ['War and Victory in Hungary: The 1663 and 1664 Hungarian Campaigns of Grand Vezir Köprülüzâde Fâzil Ahmed Pascha']. Osmanische Geschichtsschreiber Vol. 8. Ed. Richard F. Kreutel. Graz-Vienna-Cologne: Verlag Styria.

Strauss, Johann, ed. 1991. Die Chronik des Isazade. Ein Beitrag zur osmanischen Historiographie des 17. Jahrhunderts ['The Chronicle of Isazade. A Contribution to Seventeenth-Century Ottoman Historiography']. Islamkundliche Untersuchungen. Vol. 108. Berlin: Klaus Schwartz Verlag.

Szakály, Ferenc. 1989. “Az 1670-es évek Habsburg-ellenes mozgalmai és a hódoltsági magyar feudalis hatalom" ['The Anti-Habsburg Movements of the 1670s and Feudal Power in Subjugated Hungary']. A Thököly-felkelés és kora ['The Thököly Uprising and its Times']. Ed. László Benczédi. Budapest: Akadémiai Kiadó: 59-67.

Toma, Katalin. 2002. "Egy császári látogatás utóélete. I Lipót Pottendorfban, 1668” ['The Afterlife of a Visit by the Emperor Leopold I. in Pottendorf, 1668']. Fons IX/1-3: 345-58.

Trócsányi, Zsolt. 1972. Teleki Mihály. Erdély és a kurucmozgalom 1690-ig ['Mihály Teleki. Transylvania and the Kuruc Movement until 1690']. Budapest: Akadémiai Kiadó.

Szilágyi, Sándor. 1867. Rozsnyai Dávid, az utolsó török deák, történeti maradványai ['David Rozsnyai, the Last Turkish Scribe, Historical Vestiges']. Pest: n. p.

Szilágyi, Sándor, ed. 1889. Monumenta Comitialia Regni Transsylvaniae/Erdélyi országgyülési emlékek ['Records from the Transylvanian National Diets']. Vol. 14. Budapest: M. T. Akadémia.

Uzunçarş1l1, Ismail Hakk1. 1951. Osmanli tarihi ['Ottoman History']. Vol. 3, pt. 1 [“II. Selim'in tahta çıkışından 1699 Karlofca anlaşmasına kadar ('From the Ascension of Selim II to the Treaty of Karlovic in 1699')’']. No. 16 in Series XIII of Türk Tarih Kurumu Yayınlari ['Publications of the Turkish Historical Institute']. Ankara: Türk Tarih Kurumu Basimevi.

Varga, J. János. 2007. Válaszúton. Thököly Imre és Magyarország 1682-1684-ben [‘At the Crossroads. Imre Thököly and Hungary 1682-1684']. História Könyvtár Monográfiák. Vol. 23. Ed. Ferenc Glatz. Budapest: MTA Történettudományi Intézet. 
Michels, Georg B. "Myth or Reality? Ottoman Support for Hungarian Rebels in Light of a Secret Transylvanian Mission to the Porte (1669-1670)." Hungarian Cultural Studies. e-Journal of the American Hungarian Educators Association, Volume 8 (2015): http://ahea.pitt.edu DOI: 10.5195/ahea.2015.220

Várkonyi, Ágnes R. 2002. “A Wesselényi szervezkedés történetéhez 1664-1671” [“About the History of the Wesselényi Organization 1664-1671']. Eds. Pál Fodor, Géza Pálffy and István György Tóth. Tanulmányok Szakály Ferenc emlékére ['Studies Dedicated to the Memory of Ferenc Szakály’]. Budapest: MTA TKI Gazdaság- és Társadalomtörténeti kutatócsoportja: 423-460.

Von Hammer, Joseph. 1830. Geschichte des Osmanischen Reiches, grossentheils aus bisher unbenützten Handschriften und Archiven ['History of the Ottoman Empire, largely from still unutilized Manuscripts and Archives'] Vol. 6. Pest: C. A. Hartleben's Verlag. 